\title{
Retail in a Post Covid World: Reflections and Directions
}

\author{
Xiaocheng $\mathrm{Lu}^{1}$ \\ ${ }^{1}$ Birmingham Business School, College of Social Science, University of Birmingham \\ Email:XXL765@student.bham.ac.uk
}

\begin{abstract}
The coronavirus pandemic is hitting businesses across the board, especially retail. Many offline retail stores have to close stores to reduce losses. At the same time, more and more merchants choose to change their business strategy by shifting the focus of their work to the development and operation of online shopping. They need to create a new retail system to cope with offline customer loss and meet their sales targets. In addition, online operations are inseparable from effective publicity and promotion. Increased visibility can drive traffic and potential consumer orders to online retailers. In general, retailers need to redefine their relationship with consumers and build new retail systems to ensure the sustainability of their online businesses. The transformation of the offline retail industry represents the modern enterprise to adapt to the changes in society and accelerate its orientation.
\end{abstract}

\section{Keywords: Coronavirus Pandemic, New Retail System, Online Shopping, Sustainability}

\section{INTRODUCTION}

The coronavirus pandemic has had many a lot of impacts on the various players in the business world. The retailers are some of the worst hit groups. According to Oni \& Omonona (2020) [15], Covid-19 pandemic was a catalyst for many retailers closing down and has accelerated the adoption of online shopping among consumers. In essence, this is becoming the "new normal" since even though the virus is likely to be contained with time, it might take time to contain it. Most importantly, people have become more acclimatized to online way of doing things to the extent that they are now ready to embrace and reap its numerous benefits [18]. As we move towards the new normal with social distancing enabled by the latest technologies, it is essential to discuss what this will mean for the consumer and the retail services sector. In essence, there is a need to understand how the new normal affects the customer behaviour and how the retail and service is likely to change including the opportunities and challenges therein. Some of the challenges include dwindling profits, demand fluctuations, lack of a reliable way to shield customers, and identification of the most effective way of talking to customers. The reality for retailers has been changed fundamentally by the global response to this virus. In this regard, they are adapting to the new ways which might continue even in the postCovid-19 era.

\section{APPROACHES TO DEVELOPING SUCCESSFUL MARKETING IN SERVICE ORGANIZATIONS}

As a result of covid-19, retailers have been working hard to try and come up with alternative approaches to develop marketing in their organizations. According to Pentane et al. (2020) [17], the approaches are intended to make sure that the business such as organizations that handle perishable goods, continue to flourish despite the negative impacts of the pandemic impacts. The approaches include re-analysing marketing plans with coronavirus in mind and retaining and growing of customer base. This will assure retailers that their goods are reaching the intended customers safely and at the right time during the crisis. These digital approaches may also help the retailers to expand their business and make more profit than before. The retail accordion theory is applied here to do a successful marketing service in organizations; general stores that represent a small range of products should focus on a particular product.

Retailers re-analyse market plans to try and regain the disrupted supply chain by the covid- 19 crisis. They must respond to change in their marketing system and develop an effective plan that includes covid-19 rules such as hand sanitizers and toilet paper hoarding. To focus on what's next, re-centre your thinking, and re-evaluate your 
goals as a retailer. Some of the steps to follow for a successful market plan are: stop panicking and start making plans putting your health first, evaluating your tone of voice, language, and current images by reevaluating your messages and assets from the new point of view, adjusting marketing timelines and campaigns by accepting the push back of the movements and develop them a new in considerations of your family, employees and customers well-being and lastly having a positive mindset while avoiding the insensitivity by maintaining good attitudes and ensure your availability [1].

Retailers grow and retain customer base to avoid closures or reduction in the rates of sales. It can be done through performing content marketing, ensuring continued paid advertisement, social medial marketing, offering discounts and promotions, and optimizing commerce stores [6]. Content marketing involves answering your customer's questions and fills up the holes left by the campaigns paused to save resources. It can be done by performing a content audit by ensuring the information is accurate and satisfying customers, providing detailed and relevant information to your customers by talking about emerging issues in your organization, and understanding your customers to provide what they need. Keeping your paid advertising active involves keeping your advertisements running to prevent your product from being forgotten. It is better to budget than eliminate the program entirely.

Social media marketing involves advertising your goods through digital gadgets such as T.V.s and radios. It is the best way to promote since it is cheaper than other popular means such as internet ads and widely used [2]. It requires one to be there and social to set a powerful foundation for your platform. It also requires one to always be part of the conversation by stating and engaging in discussion with the community for better understanding of your customer's needs. Offering discounts and promotions involves making deals with customers, such as economic recession, which attracts the attention of price-conscious customers. Optimizing commerce stores consists of making sure your store is optimized for usability and findability. It is done by evaluating your homepage, which introduces your customers to your business. Optimizing your product pages creates product and meta-descriptions, title tags, headers, and copy [9]. It also increases your page load speed not to exhaust the customers.

\section{INFLUENCE OF PLACE ON BUYER BEHAVIOUR AND THE CUSTOMER EXPERIENCE}

Covid-19 has affected many places globally and has caused many changes in customer behaviours and experiences. In the areas where coronaviruses cases are rampant, customers have minimized physical shopping behaviours [4]. The amount of shopping has also declined, and most of the advertisements on social media are covid19 related instead of goods and services the customers are interested in buying. It has also increased customer's experiences such as the use of online shopping, requesting for home delivery, and experience on their health such as the use of hand sanitizers to kill the virus. Wheel retailing theory is evidenced as these are macroenvironmental variables affecting customer's behaviour and experience.

In some places, people have changed their behaviours of attending the shopping centres regularly due to fear of covid-19. As a result, the retailers have undergone losses, and others have ended up shutting down their businesses. Some countries have completely shut down movement and have lifted stay-at-home orders, which have prevented many consumers from accessing their goods, especially if not offered online. Also, when customers visit the shopping centres, there is a high possibility of purchasing more than when ordering online. Advertisements introduce the goods and services to the users. Some retailers have pulled down the ads to save some cash, and coronavirus news has covered social media. As a result, the consumers are not introduced to the new goods, and some even forget the goods they used to buy [7]. Therefore, consumer behaviour is impacted given ongoing risks of potential resurgences, supply chain disruptions, and uncertainties in locked-down places.

Covid-19 also has positive impacts on the customer's experience. It has introduced the consumers to a digital world where online ordering is the most practiced form of shopping in places with lockdowns [12]. People in such areas not only order the goods online but also request a home delivery offer, which can sometimes be costly as some organizations may charge more. In contrast, others may offer free deliveries and be advantageous to the customers. These online trending shifts are sustainable to its customers and do not seem to be stopping soon. This is also helpful to retailers as the charge on delivery helps increase their productions and keep their businesses going.

\section{COMPLEX RELATIONSHIPS WITH BOTH CUSTOMERS AND SUPPLIERS}

This is the relationship in terms of deliveries, complaint handling, the value of the product and services presented between the supplier and the customer. They both have the same aim of satisfying the final consumer of goods and services they provide. However, the relationship between these two appears complex as they are both aware of improving their working capital. It works in both directions where both the customer and the supplier benefits in return. The supplier needs the capital at hand, and the customer is interested in the goods offered by the supplier [3]. However, to maintain a good relationship with both customers and suppliers, one 
should: check suppliers with good values, loyalty, timely feedback, communication, becoming a great customer, and understanding the needs of your supplier. Retail life cycle theory is evidenced here as both the customer and the supplier must undergo the identifiable stages to make a good relationship between them.

Choosing the right and well rated suppliers means that they align with your values. The warranties or return policies match yours. It very hard for two people who differ in core values to reason the same, and as a result, you live with complains or feel uncomfortable around such individuals. Loyalty means choosing a customer who can never betray you. Some customers always run for the best deals, which should not be the case [5]. Customers should remain loyal to the supplier and discuss in case of misunderstands. Timely feedback means tackling mistakes and planning professionally. Both should schedule their time well and avoid yelling at each other if things do not go as expected. Communication involves both the customer and the supplier always keeping in touch. Both of them should even meet up and hold a short meeting to discuss what is working well and what is not. Becoming a good customer means doing what you would like them to do to you. The things you would love the supplier to do are exactly how you should do to them. Lastly, understanding the needs of your supplier means respecting their way of doing things. This way, both sides will be satisfied, and no quarrels can arise.

\section{UNDERSTANDING CURRENT LOGISTICAL ISSUES}

The pandemic of covid-19 has caused many retailers running the business to feel as there is too much to handle. The logistical issues have fuelled the cost and time of running the business, which is becoming a burden to the retailers. This has led to many shutting down their business and others adapting the new normal way of handling business online. The retailers' logistical issues include technology strategy and implementation, environment-related issues, government regulations, improved customer service, driver's shortage and retention, business process improvement, economy, and fuel costs. In the post-covid-19 era, these issues might stick into customer's minds, and the only option of the retailers will be adapting the new normal. The wheel retailing theory supports this idea as the business life cycle changes to a different new one.

To start with, the lockdowns have restricted many customers from reaching out to their suppliers. This has led to some companies coming up with a new way of reaching its goods to the consumers. Fuel prices a fluctuation is becoming a barrier to transportation services as it sometimes becomes more costly to handle. For example, the rise of diesel prices can increase the cost of using diesel-engine vehicles while transporting goods and services to the intended customers [10]. Again, business process improvement is another issue affecting the retail sectors of businesses around the world. Improving business processes by adopting the new digital technologies is becoming the only option for retailers to run their businesses effectively. This opportunity to enrol in online platforms may seem enticing, but they are very overwhelming. Time, cost, and skilled personnel are required to have these improved processes working effectively. Improved customer service is yet another barrier to the retailers. The customers need full transparency where services such as home delivery of goods are available all through. As the request of deliveries is increasing the willingness of the customers to pay for fast delivery, have decreased with some expecting free deliveries.

The economic logistic issue hits in, taking a greater toll on the U.S. economy due to the rising inflationary demand, greater credit crisis, and fuel price fluctuations. Reduced incomes also pressure the industries due to fewer workers, declined requests due to the poor economy on the customer's side, and compliance with government regulations due to covid-19 precautions. Driver shortages due to the reduced number of workers in the industries are also major barriers affecting business systems. Therefore, transportation of goods and services to the intended consumers are minimized, reducing the incomes of the sectors. Government regulations contain strict rules to be followed by the retailers, such as keeping the customer's good health, reducing the number of workers, and restricting movement, which becomes too much for some retailers to handle [14]. Environmental issues such as emissions of gasses and maintaining a healthy environment have been too much of concern for the retailers in terms of higher expenses and low incomes due to fewer customers. And lastly, technology strategy and complementation carry many advantages to both the customers and the retailers. Still, the problem comes in as it is expensive and requires skilled labour to improve and implement them.

\section{POSSIBLE PROBLEMS ENCOUNTERED BY SERVICE AND RETAIL ORGANIZATIONS}

As the pandemic continues with its negative impact on businesses, organizations continue to face many problems while trying to safely deliver goods and services to consumers and make good interactions with its customers. The problems include supply chain management, encouraging digital and contactless payments, keeping up with changing customer expectations, and attracting and retaining customers [13]. In approaching post-covid-19 world, with the aid of the current impressive technology, industries and companies are likely to develop solutions to these problems [20]. The theory of natural selection supports this idea of the 
retailers adapting the problems and coming up with an effective change to solve the arising issues.

Supply chain management has become a problem for service and retail organizations. They are forced to repurpose their management strategies to meet the customer's needs in the new era of covid-19. Until postcovid-19, the retailers need to have a streamlined mannered plan of their inventories and logistics. Encouraging digital and contactless payments is another problem facing retail organizations as digital payments require retailers to invest in technologies that will enable and support the task, adding an extra cost [16]. Such technologies include Plutus QR, which allows customers to pay using code Q.R. and gives an option of a quick scan. Keeping up with changing customers' expectations involves the retailer adapting the new behaviours of the customer and making sure they are solved [11]. It is only through an analysis where the retailer can fully understand the customer's needs, which adds extra expenses. Attracting and retaining customers involves bringing back and holding both online and offline customers during the pandemic era. Ensuring safety measures to offline customers who might be scared to move out of their houses and acquiring loyal customers who cannot run for cheap offers has been the major challenge to service and retail organizations.

\section{CONCLUSION}

In post-covid-19, retailers will have to develop solutions such as offering deals and using loyalty points to make cashless payments to attract and retain customers [19]. They are adapting and keeping up with customer expectations to create a good relationship with the customers. Integration of third-party billing apps can help in reconstructing the management of the retail sector new. The relationship between the customer and the supplier is for a lifetime. No matter the negative impacts of covid-19 causes, the customer will still require the goods, and the supplier will need cash at hand to run their businesses. The government should also intervene and solve some of the logistics issues facing the business systems, such as solving the fuel fluctuations problems. Movements of goods are the heart of economic recovery as the world is adjusting to the new normal. Therefore, logistic providers need to automate and optimize as first as possible as they collaborate with others to make the retail sector work effectively. This will ensure a perfect and suitable retail sector once the pandemic is over. With our retail sector's problems solved, we are assured of a bright future with generations to come after the covid-19 crisis.

\section{REFERENCES}

[1] Balis, J., 2020. Brand marketing through the coronavirus crisis. Harvard Business Review.
[2] Chiang, I.-P. 2019. Exploring the Benefits of Social Media Marketing for Brands and Communities. International Journal of Electronic Commerce Studies, 10(2), 113-140.

[3] Emiliani, M.L., 2010. Historical lessons in purchasing and supplier relationship management. Journal of Management History.

[4] Friesen, C. A. 2020. Shopping for Food During COVID-19 Pandemic. Journal of Nutrition Education and Behaviour, 52, 11, 1082-1083.

[5] Gadde, L.E. and Snehota, I., 2000. Making the most of supplier relationships. Industrial marketing management, 29(4), pp.305-316.

[6] Gronroos, C., 1990. Relationship approach to marketing in service contexts: The marketing and organizational behaviour interface. Journal of business research, 20(1), pp.3-11.

[7] Hasanat, M.W., Hoque, A., Shikha, F.A., Anwar, M., Hamid, A.B.A. and Tat, H.H., 2020. The impact of coronavirus (COVID-19) on e-business in Malaysia. Asian Journal of Multidisciplinary Studies, 3(1), pp.85-90.

[8] Ihle, R., Rubin, O.D., Bar-Nahum, Z., \& Jongeneel, R.A. 2020. Imperfect food markets in times of crisis: economic consequences of supply chain disruptions and fragmentation for local market power and urban vulnerability. Food Security 12 (2020).

[9] Kang, J., Diao, Z. and Zanini, M.T., 2020. Businessto-business marketing responses to COVID-19 crises: a business process perspective. Marketing Intelligence \& Planning.

[10] Kumar, A., Luthra, S., Mangla, S.K. and Kazançoğlu, Y., 2020. COVID-19 impact on sustainable production and operations management. Sustainable Operations and Computers, 1, pp.1-7.

[11] Kusuma, B., Prasad, N.D. and Rao, M.S., 2013. A study on organized retailing and its challenges and retail customer services. Innovative Journal of Business and Management, 2(5), pp.97-102.

[12] Lemon, K.N. and Verhoef, P.C., 2016. Understanding customer experience throughout the customer journey. Journal of Marketing, 80(6), pp.69-96.

[13] Lentine, K. L., Mannon, R. B., \& Josephson, M. A. 2021. Practicing With Uncertainty: Kidney Transplantation During the COVID-19 Pandemic. American Journal of Kidney Diseases: the Official Journal of the National Kidney Foundation, 77, 5, 777-785. 
[14] O'Laughlin, K.A., Cooper, J. and Cabocel, E., 1993. Reconfiguring European logistics systems.

[15] Oni, O. \& Omonona, S. 2020. The effect of COVID19 on small retail. The Retail and Marketing Review, 16(3), 48-57.

[16] Ograjensek, I., Gustin, H. A., Kalajanović, I., Marash, M., \& Huo, S. 2020. The impact of COVID19 on the retail sector. The Virus Aftermath, 119-132

[17] Pantano, E., Pizzi, G., Scarpi, D., \& Dennis, C. 2020. Competing during a pandemic? Retailers'ups and downs during the COVID-19 outbreak. Journal of Business Research, 116, 209-213.

[18] Rachidi, M. F. 2020. Implications of the COVID-19 pandemic on management of human

capital. Journal of Public Administration, 55, 4, 688-700.

[19] Schellhase, R., Hardock, P. and Ohlwein, M., 2000. Customer satisfaction in business-to-business marketing: The case of retail organizations and their Suppliers. The Journal of Business and Industrial Marketing, 15(2-3), pp.106-121.

[20] Zentes, J., Morschett, D. and Schramm-Klein, H., 2007. Strategic retail management. Springer 